(c) American Dairy Science Association, 2005.

\title{
Ovarian Activity and Reproductive Performance of Dairy Cows Fed Different Amounts of Phosphorus
}

\author{
S. K. Tallam, A. D. Ealy, ${ }^{\star}$ K. A. Bryan, and Z. Wu \\ Department of Dairy and Animal Science, Pennsylvania State University, University Park 16802
}

\section{ABSTRACT}

Fifty-four multiparous Holsteins were utilized to determine the effect of dietary $\mathrm{P}$ on ovarian activity and reproductive performance. Cows were assigned at calving to diets containing 0.35 or $0.47 \%$ P. Ovarian activity was monitored 3 times weekly by ultrasonography, beginning $10 \mathrm{~d}$ after parturition until the end of a $60-\mathrm{d}$ voluntary waiting period. After this period, cows were synchronized and bred using the Ovsynch protocol. During wk 2 of lactation, the number of small ( 3 to 5 $\mathrm{mm}$ in diameter) and large $(>9 \mathrm{~mm})$ follicles was similar between groups, but the number of medium ( 6 to $9 \mathrm{~mm}$ ) follicles was lower for $0.35 \% \mathrm{P}$ than for $0.47 \% \mathrm{P}(1.2$ vs. 1.9). Dietary $P$ did not affect the number of days to first postpartum ovulation or the diameter of dominant and ovulating follicles. The multiple ovulation rate and the proportion of cows that were anovulatory or developed follicular cysts did not differ between groups. Dietary $\mathrm{P}$ amount did not influence corpus luteum development or blood progesterone concentration during the voluntary waiting period. The first service conception rate and pregnancy loss from 30 to $60 \mathrm{~d}$ after breeding were not affected. The overall pregnancy rate during the first $200 \mathrm{~d}$ of lactation (60.9 and $60.0 \%)$ and the number of services per pregnancy (2.1 and 1.9) did not differ between groups. Serum inorganic $\mathrm{P}$ was elevated from 6 to $7 \mathrm{mg} / \mathrm{dL}$ during the first 3 mo postpartum as dietary $\mathrm{P}$ was increased. Fecal $\mathrm{P}$ content measured during the first $16 \mathrm{wk}$ of lactation averaged 0.63 and $0.89 \%, 29 \%$ lower for the $0.35 \% \mathrm{P}$ group. Mean milk yield during the first $40 \mathrm{wk}$ of lactation did not differ, averaging 40.5 and $39.0 \mathrm{~kg} / \mathrm{d}$ for the 0.35 and $0.47 \% \mathrm{P}$ groups, respectively. Overall, varying dietary $\mathrm{P}$ from 0.35 to $0.47 \%$ did not affect postpartum ovarian activity, reproductive performance, or milk production.

(Key words: dairy cow, phosphorus requirement, reproductive performance, ovarian activity)

Received January 27, 2005.

Accepted March 17, 2005.

Corresponding author: Z. Wu; e-mail: ziw1@psu.edu.

*Current address: Department of Animal Sciences, University of Florida, Gainesville, FL 32611.

\section{INTRODUCTION}

Recent studies (Wu and Satter, 2000; Wu et al., 2000; Lopez et al., 2004b) have shown similar milk production when the $\mathrm{P}$ content of the diet for dairy cows is varied, but producers often feed $\mathrm{P}$ in excess of the requirements suggested by NRC $(1989,2001)$ (Dou et al., 2003). The primary reason for the overfeeding is the perception that supplemental $\mathrm{P}$ enhances reproductive performance.

The link between $\mathrm{P}$ and reproduction can be traced to some early field studies (Theiler et al., 1928) that reported improved reproductive performance when cattle grazing P-deficient rangelands were supplemented with P. Although similar results were observed in some subsequent studies (Hignett and Hignett, 1952; Scharp, 1979), other studies (Noller et al., 1977; Carstairs et al., 1980) reported no such effect. Recent studies specifically designed to evaluate the effect of dietary $\mathrm{P}$ on milk production also suggested that $\mathrm{P}$ supplementation does not enhance reproductive performance. Wu and Satter (2000) summarized 8 studies involving 785 cows where one-half of the cows was fed low $\mathrm{P}$, ranging from 0.32 to $0.40 \%$ of the diet, and the other one-half was fed high $P$, ranging from 0.39 to $0.61 \%$ of the diet. Means of reproductive measurements, including days to first estrus, days to first breeding, number of services per conception, and pregnancy rates, were not different between dietary treatments.

Reduced calf crops, lowered conception rates, and altered estruses have been reported with $\mathrm{P}$ deficiency; however, there has been no specific mechanism of action established to explain the role of $\mathrm{P}$ in reproduction. Hurley et al. (1982) reported that heifers fed 0.19, 0.37, or $0.64 \% \mathrm{P}$ did not differ in mounting behavior or blood serum concentrations of progesterone, estradiol, and $\mathrm{LH}$ during $48 \mathrm{~h}$ after injection of $\mathrm{PGF}_{2 \alpha}$. However, heifers fed the lowest $P$ amount attained estrus earlier than those fed the medium and high amounts of P. Hignett and Hignett (1952) and Carnahan (1974) showed changes in expression of estrus in cows fed diets deficient in P. However, more recent studies (Lopez et al., 2004a,c) showed no difference in the length of estrous cycle, estrus duration, or mounting pattern when cows were fed 0.38 or $0.48 \%$ and 0.37 or $0.57 \% \mathrm{P}$. 
Table 1. Ingredient and nutrient content of diets (DM basis).

\begin{tabular}{lcc}
\hline & \multicolumn{2}{c}{ Diet } \\
\cline { 2 - 3 } Item & $0.35 \% \mathrm{P}$ & $0.47 \% \mathrm{P}$ \\
\cline { 2 - 3 } & & \\
\cline { 2 - 3 } Ingredient content & 3.4 & 3.4 \\
Alfalfa hay & 26.4 & 26.3 \\
Alfalfa silage & 26.4 & 26.3 \\
Corn silage & 18.2 & 18.1 \\
Corn, high moisture, ground & 5.1 & 5.0 \\
Soybeans, ground roasted & 20.5 & 20.4 \\
Protein and mineral mix ${ }^{1}$ & - & 0.5 \\
Monosodium phosphate & & \\
Nutrient analysis & 18.1 & 18.1 \\
CP & 18.6 & 18.5 \\
ADF & 28.5 & 28.4 \\
NDF & 0.35 & 0.47 \\
P & & \\
\hline
\end{tabular}

${ }^{1}$ Mix consisted of $40.5 \%$ ground shelled corn, $17.8 \%$ soybean meal (48\% CP), $18.1 \%$ SoyPass, $4.1 \%$ fish meal, $4.1 \%$ blood meal, $3.8 \%$ tallow, and $11.6 \%$ mineral and vitamin supplements. Each kilogram of the mix contained $17.4 \mathrm{~g}$ of $\mathrm{Ca}, 5.4 \mathrm{~g}$ of $\mathrm{P}, 9.3 \mathrm{~g}$ of $\mathrm{Mg}, 13.0 \mathrm{~g}$ of $\mathrm{K}, 17.9 \mathrm{~g}$ of $\mathrm{Na}, 13.7 \mathrm{~g}$ of $\mathrm{Cl}, 30,000 \mathrm{IU}$ of vitamin A, $7000 \mathrm{IU}$ of vitamin $\mathrm{D}$, and $119 \mathrm{IU}$ of vitamin $\mathrm{E}$.

The observed changes in estrous characteristics in some of the earlier studies would suggest that follicular development is altered in P-deficient cows. However, the majority of the recent studies suggested that varying dietary $\mathrm{P}$ at practical levels does not affect milk production or reproductive performance. It is recognized that the primary focus of the recent studies was lactation performance, and, consequently, only limited reproductive physiology data were obtained. There is a need for more information on the effect of $\mathrm{P}$ on specific reproductive physiology. The objective of this study was to examine the relationship between dietary $\mathrm{P}$ content and ovarian activity. Specifically, changes in ovarian follicular development and corpus luteum function caused by reducing $\mathrm{P}$ to NRC (2001) requirements were determined. We hypothesized that the ovarian activity postpartum and reproductive performance are not affected by such a reduction.

\section{MATERIALS AND METHODS}

The experiment was conducted using a protocol that was approved by the Pennsylvania State University Institutional Animal Care and Use Committee.

\section{Animals, Diets, and General Management}

Fifty-four multiparous Holsteins were paired by parity, 305-d mature equivalent milk yield, and projected calving date. Cows were assigned randomly within pairs at calving to one of 2 diets containing either 0.35 or $0.47 \% \mathrm{P}$ (Table 1 ). The lower $\mathrm{P}$ amount was consistent with the required level based on NRC (2001) recommendations for cows (averaging $39.8 \mathrm{~kg} / \mathrm{d}$ of milk) used in the trial, and the diet was formulated without using supplemental $\mathrm{P}$ sources. The higher $\mathrm{P}$ amount was obtained by including monosodium phosphate in the low $\mathrm{P}$ diet. Alfalfa silages 1 and 2 ( 2 silos) were used in equal proportion during the first half of the trial, but only silage 2 was used during the second half.

Immediately after calving, cows were moved from maternity pens to a tie-stall barn where they were housed during the trial. Diets were offered as a TMR at approximately 0800 and $1500 \mathrm{~h}$ for ad libitum consumption on a group basis. Feed consumed and orts were recorded daily for each treatment group. Body condition scores $(1=$ thin to $5=$ fat; Edmonson et al., 1989) were recorded at calving and once monthly thereafter until cows were bred. Cows were milked twice daily at 0500 and $1700 \mathrm{~h}$. Milk yield data were based on DHIA records obtained every 4 wk. The experiment lasted $200 \mathrm{~d}$. After $200 \mathrm{~d}$ postcalving, cows continued with their respective diets until wk 40 of lactation, and milk yield obtained during this period was combined with the data obtained during the trial for statistical analysis.

Milk samples were collected every other week during the trial, preserved with 2-bromo-2-nitropropane-1,3diol, and analyzed for fat, protein, lactose, and MUN by the Pennsylvania DHIA Laboratory (University Park) using infrared spectroscopy (Fossomatic 4000 MilkoScan; Foss Electric, Hillerød, Denmark) and for SCC using a cell counter (Fossmatic 400; Foss Electric). Feed ingredients were collected once weekly and analyzed for DM by air-drying in an oven at $55^{\circ} \mathrm{C}$ for $48 \mathrm{~h}$. Fecal samples were collected per rectum approximately $5 \mathrm{~h}$ after the a.m. feeding every $4 \mathrm{wk}$ and dried at $55^{\circ} \mathrm{C}$.

Dried feed and fecal samples were ground through a Wiley mill (Arthur H. Thomas, Philadelphia, PA) with a 1-mm screen. After grinding, grain samples were further pooled to generate composite samples every $4 \mathrm{wk}$. These composite grain samples, the weekly forage samples, and the fecal samples were analyzed for CP using a Kjeldahl digestion system (Kjelter Tecator 2020; Höganäs, Sweden) and flow injection colorimetry (QuikChem Method 15-107-06-2-F, QuickChem FIA+ 8000 Series; Lachat Instruments, Milwaukee, WI) according to the AOAC (1990) and for NDF (heat-stable $\alpha$-amylase and $\mathrm{Na}_{2} \mathrm{SO}_{3}$ were used) and ADF according to Robertson and Van Soest (1981). The ANKOM ${ }^{200}$ Fiber Analyzer incubator (ANKOM Technology, Fairport, NY) was used for NDF and ADF analyses. Feed and fecal samples were analyzed for $\mathrm{P}$ using the preparation for Kjeldahl $\mathrm{N}$ by the same flow injection colorimetry (QuikChem Method 15-115-01-2-C, QuickChem FIA+ 8000 Series; Lachat Instruments). Certified commercial 
standards for N (LC17940-1) and P (LC18590-1) (LabChem Inc., Pittsburg, PA) were used to ensure accuracy in the analyses using the flow injection colorimetry. Nutrient content of the TMR was computed from the average nutrient content of the individual ingredients.

\section{Ovarian Activity and Reproductive Management}

Ovarian follicular activity was monitored 3 times weekly by intrarectal examination using a real-time, B-mode diagnostic ultrasound scanner equipped with a linear array 7.5-MHz transducer (PIE Scanner 200; Classic Medical Supply Inc., Tequesta, FL) starting 10 $\mathrm{d}$ after calving until the end of a 60-d voluntary waiting period. During each ultrasound scanning, the position of the ovarian structures was recorded on sonographic printouts from a video graphic printer (Sony Video Graphic Printer, Model UP-895MD; Sony Corp., Tokyo, Japan) attached to the ultrasound unit. Ultrasound images of ovarian structures were mapped using the method described by Sirois and Fortune (1988). The population of small (3 to $5 \mathrm{~mm}$ in diameter), medium (6 to $9 \mathrm{~mm}$ ), and large $(>9 \mathrm{~mm})$ follicles was recorded. The diameters of the corpus luteum and the dominant, subordinate, and ovulating follicles were also recorded.

Starting from calving until the first service pregnancy diagnosis, blood samples $(10 \mathrm{~mL})$ were collected 5 $\mathrm{h}$ after the a.m. feeding into nonheparinized vacutainer tubes (Becton-Dickinson, Franklin Lakes, NJ) 3 times weekly from the coccygeal vein. The samples were cooled on ice and centrifuged within $24 \mathrm{~h}$ at $1000 \times g$ for 20 min. Harvested serum was stored at $-20^{\circ} \mathrm{C}$. Serum progesterone concentration was determined using a previously validated solid-phase radioimmunoassay (Coat-A-Count; Diagnostic Products, Los Angeles, CA). Weekly serum samples from wk 1 to 3 and monthly serum samples for the first 3 mo of lactation were used to quantify peripheral $\mathrm{Ca}$ and $\mathrm{P}$ concentrations. Calcium concentration was determined using a quantitative colorimetric procedure (Stanbio Total LiquiColor, Procedure No. 0155; Stanbio Laboratories, Boerne, TX), and $\mathrm{P}$ concentration was determined using a direct quantitative UV procedure (Stanbio Phosphorus LiquiUV, Procedure No. 0830; Stanbio Laboratories).

The number of days to first postpartum ovulation was determined by ultrasound examination and on the basis of the day when serum progesterone concentrations were $>1 \mathrm{ng} / \mathrm{mL}$. After the 60 -d voluntary waiting period, all cows were synchronized using the Ovsynch procedure (Pursley et al., 1995). Briefly, on $d-10$ before timed AI, cows received an i.m. injection of $50 \mu \mathrm{g}$ of GnRH (gonadorelin hydrochloride, Factrel; Fort Dodge Animal Health, Fort Dodge, IA); on d -3 , they received $25 \mathrm{mg}$ of $\mathrm{PGF}_{2 \alpha}$ (Lutalyse; Pharmacia Animal Health,
Kalamazoo, MI); and on $\mathrm{d}-1$, they received $50 \mu \mathrm{g}$ of GnRH. Artificial insemination by the same technician was conducted 12 to $18 \mathrm{~h}$ after the second GnRH administration. The Ovsynch protocol was initiated on the same day of the week (Monday) for all cows. Pregnancy diagnosis was performed 28 to $35 \mathrm{~d}$ after $\mathrm{AI}$ using intrarectal ultrasonography. Cows diagnosed open were resynchronized and bred using the same Ovsynch protocol. Cows diagnosed open during a given week were enrolled in the Ovsynch protocol the following week. A final ultrasound pregnancy confirmation for cows diagnosed pregnant 28 to $35 \mathrm{~d}$ after AI was performed 25 to $32 \mathrm{~d}$ later to determine any early pregnancy losses.

\section{Statistical Analyses}

Data involving nonrepeated measurements were evaluated by one-way ANOVA using the GLM procedure of SAS (1999). These included days to first ovulation; diameter of the corpus luteum and the subordinate, dominant, and ovulating follicles; duration of the first postpartum estrous cycle; and days to the first postpartum ovulation. Data involving repeated measurements, including milk production and serum concentrations of progesterone, $\mathrm{P}$, and $\mathrm{Ca}$, were analyzed with the PROC MIXED procedure of SAS (1999) using the following model:

$$
\mathrm{Y}_{\mathrm{ijk}}=\mu+\mathrm{D}_{\mathrm{i}}+\mathrm{C}(\mathrm{D})_{\mathrm{j}}+\mathrm{T}_{\mathrm{k}}+\mathrm{DT}_{\mathrm{ik}}+\mathrm{e}_{\mathrm{ijk}}
$$

where $\mathrm{Y}_{\mathrm{ijk}}=$ observation, $\mu=$ overall mean, $\mathrm{D}_{\mathrm{i}}=$ effect of diet, $C(D)_{j}=$ effect of cow $\mathrm{j}$ nested within diet, $\mathrm{T}_{\mathrm{k}}=$ effect of time (day or week), $\mathrm{DT}_{\mathrm{ik}}=$ interaction of diet and time, and $\mathrm{e}_{\mathrm{ijk}}=$ residual error.

Comparisons involving categorical data, including incidence of anovulation, cystic follicles, percentage of cows responding to the Ovsynch procedure, and pregnancy rates, were evaluated by $\chi^{2}$ and Fisher's exact tests using the FREQ procedure of SAS (1999). For all analyses, treatment differences were considered significant at $P<0.05$, unless otherwise indicated.

\section{RESULTS AND DISCUSSION}

\section{Nutrient Content of Diets}

Feed ingredients were relatively constant in nutrient content during the study (Table 2). Alfalfa hay and alfalfa silage 1 were of relatively poor quality. The CP content of these forage sources was low, and the NDF and $\mathrm{ADF}$ content was high, compared with the content listed in NRC (2001). Other ingredients were normal. The diets were similar in the content of $\mathrm{CP}, \mathrm{NDF}$, and $\mathrm{ADF}$, averaging 18,19 , and $28 \%$ for these nutrients, 
Table 2. Analyses of dietary ingredients.

\begin{tabular}{|c|c|c|c|c|c|}
\hline Ingredient & $\mathrm{DM}$ & $\mathrm{CP}$ & NDF & $\mathrm{ADF}$ & $\mathrm{P}$ \\
\hline & & & $-(\%)$ & 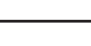 & - \\
\hline \multicolumn{6}{|c|}{ Alfalfa hay $(\mathrm{n}=33)$} \\
\hline Average & 82.3 & 14.8 & 59.2 & 36.4 & 0.32 \\
\hline $\mathrm{SE}$ & 0.7 & 0.6 & 1.5 & 0.4 & 0.01 \\
\hline \multicolumn{6}{|c|}{ Alfalfa silage $1(n=43)$} \\
\hline Average & 28.4 & 17.7 & 51.7 & 41.2 & 0.41 \\
\hline $\mathrm{SE}$ & 0.8 & 0.4 & 1.1 & 0.9 & 0.01 \\
\hline \multicolumn{6}{|c|}{ Alfalfa silage $2(\mathrm{n}=16)$} \\
\hline Average & 37.4 & 22.9 & 40.5 & 34.9 & 0.29 \\
\hline $\mathrm{SE}$ & 1.1 & 1.2 & 1.9 & 2.4 & 0.04 \\
\hline \multicolumn{6}{|c|}{ Corn silage $(n=43)$} \\
\hline Average & 36.0 & 7.4 & 40.3 & 23.6 & 0.24 \\
\hline $\mathrm{SE}$ & 0.4 & 0.1 & 0.7 & 0.4 & 0.01 \\
\hline \multicolumn{6}{|c|}{ High moisture corn $(\mathrm{n}=11)$} \\
\hline Average & 74.9 & 9.2 & 11.4 & 3.6 & 0.34 \\
\hline $\mathrm{SE}$ & 0.9 & 0.3 & 0.6 & 0.2 & 0.01 \\
\hline \multicolumn{6}{|c|}{ Soybeans, roasted $(\mathrm{n}=11)$} \\
\hline Average & 91.8 & 38.0 & 14.7 & 11.3 & 0.62 \\
\hline SE & 0.3 & 0.8 & 0.4 & 0.4 & 0.01 \\
\hline
\end{tabular}

respectively (Table 1 ). The $\mathrm{P}$ content was 0.35 and $0.47 \%$ for the 2 diets.

\section{Postpartum Follicular Growth}

Resumption of ovarian follicular development was evaluated by quantifying the number of follicles $\geq 3 \mathrm{~mm}$ in diameter during the 2 nd wk postpartum. During this period, small ( 3 to $5 \mathrm{~mm}$ ), medium ( 6 to $9 \mathrm{~mm}$ ), and large $(>9 \mathrm{~mm})$ follicles were observed in all cows, indicating resumption of ovarian follicular development (Table 3). Dietary P showed no effect on the number of small or large follicles, but there was a tendency $(P=0.06)$ for the number of medium follicles to be lower for the low $\mathrm{P}$ group than for the high $\mathrm{P}$ group. The number of medium follicles is an indicator of follicular dominance because the dominant follicle has an inhibitory effect on the growth of subordinate follicles (Fortune et al., 1991). As the inhibitory effect of the dominant follicle declines, a new wave of follicular growth emerges followed by an increase in the number of medium follicles. Accordingly, the tendency for fewer medium follicles in the low $\mathrm{P}$ group may indicate a prolonged dominance and a delayed emergence of a new wave of follicular growth compared with the high P group. Diameters of the dominant or subordinate follicles did not differ between di-

Table 3. Postpartum ovarian follicular and corpus luteum measurements for cows fed diets containing 0.35 or $0.47 \% \mathrm{P}$.

\begin{tabular}{|c|c|c|c|c|}
\hline \multirow[b]{2}{*}{ Item } & \multicolumn{2}{|c|}{ Diet } & \multirow[b]{2}{*}{ SEM } & \multirow[b]{2}{*}{$P$} \\
\hline & $0.35 \% \mathrm{P}$ & $0.47 \% \mathrm{P}$ & & \\
\hline \multicolumn{5}{|l|}{ Second week of lactation } \\
\hline \multicolumn{5}{|l|}{ Number of follicles } \\
\hline Small (3 to $5 \mathrm{~mm}$ ) & 4.6 & 4.4 & 0.6 & 0.81 \\
\hline Medium (6 to $9 \mathrm{~mm}$ ) & 1.2 & 1.9 & 0.3 & 0.06 \\
\hline Large $(>9 \mathrm{~mm})$ & 1.0 & 1.0 & 0.2 & 0.82 \\
\hline Diameter of dominant follicle, $\mathrm{mm}$ & 12.5 & 12.4 & 1.0 & 0.95 \\
\hline Diameter of subordinate follicle, $\mathrm{mm}$ & 9.1 & 8.7 & 0.8 & 0.73 \\
\hline Diameter of first ovulating follicle, $\mathrm{mm}$ & 16.8 & 15.9 & 0.8 & 0.48 \\
\hline \multicolumn{5}{|l|}{ First wave of first estrous cycle } \\
\hline \multicolumn{5}{|l|}{ Number of follicles } \\
\hline Small (3 to $5 \mathrm{~mm}$ ) & 4.6 & 4.4 & 0.6 & 0.81 \\
\hline Medium (6 to $9 \mathrm{~mm}$ ) & 2.9 & 2.3 & 0.4 & 0.38 \\
\hline Large $(>9 \mathrm{~mm})$ & 1.3 & 1.1 & 0.2 & 0.48 \\
\hline Diameter of dominant follicle, $\mathrm{mm}$ & 16.5 & 13.9 & 0.9 & 0.06 \\
\hline Diameter of subordinate follicle, $\mathrm{mm}$ & 10.6 & 9.7 & 0.6 & 0.37 \\
\hline Diameter of the corpus luteum, ${ }^{1} \mathrm{~mm}$ & 23.6 & 21.9 & 1.3 & 0.33 \\
\hline
\end{tabular}

\footnotetext{
${ }^{1}$ Maximum diameter during the first wave of follicular development.
} 
etary P groups. The characteristics of postpartum ovarian follicular development during the 2nd wk of lactation were comparable with those reported previously (Schmitt et al., 1996; Tallam et al., 2003), suggesting that cows resumed antral follicular development soon after parturition.

The first postpartum dominant follicle either ovulates, regresses, and is subsequently replaced by another or persists and becomes cystic (Beam and Butler, 1998; Tallam et al., 2003). In the present study, the fate of the dominant follicles present during the first 2 wk postpartum was not influenced by dietary $\mathrm{P}$ amount. The proportion of the dominant follicles that ovulated, regressed, or became cystic was $52.2,39.1$, and $8.7 \%$, respectively, for cows fed $0.35 \% \mathrm{P}$, compared with 52.0 , 44.0 , and $4.0 \%$ for cows fed $0.47 \% \mathrm{P}$. The proportion of the dominant follicles that ovulated was lower, and the proportion of those follicles that regressed was greater, than the proportions reported in other studies (Beam and Butler, 1998; Tallam et al., 2003), suggesting that postpartum resumption of cyclic activity might have been delayed in the present study. It is the failure of ovulation rather than inhibited emergence of preovulatory follicles that delays the resumption of ovarian cyclicity. In the present study, dietary P did not influence resumption of follicular development, as indicated by the presence of the dominant follicles of $>10 \mathrm{~mm}$ in diameter in both groups of cows by the 2 nd wk of lactation. The mean diameters of the dominant follicles were similar (12.5 and $12.4 \mathrm{~mm}$ for cows fed 0.35 and $0.47 \%$ $\mathrm{P}$, respectively) and were consistent with the range reported for Holstein cows during the postpartum period. Beam and Butler (1998) reported the presence of 10 $\mathrm{mm}$ follicles by 9 DIM and a mean diameter of $13 \mathrm{~mm}$ during the 2 nd wk postpartum. Similarly, Tallam et al. (2003) reported the presence of large dominant follicles that had a mean maximum diameter of $17 \mathrm{~mm}$ in multiparous cows during the 2 nd wk of lactation. The diameters of the first postpartum ovulating follicles were not different between treatment groups (16.8 vs. $15.9 \mathrm{~mm}$; Table 3). During the first wave of follicular development following the first postpartum ovulation, the numbers of follicles of all size categories were not different between treatment groups. Similarly, the diameters of the subordinate follicle and corpus luteum during this period did not differ because of diet, although the diameter of the dominant follicles tended to be larger for the low $\mathrm{P}$ group ( 16.5 vs. $13.9 \mathrm{~mm} ; P=0.06$ ).

First postpartum ovulation indicates completion of recovery from hormonal influences of pregnancy and resumption of normal preovulatory ovarian activity. It is also indicative of the re-establishment of characteristic LH secretion that is necessary for normal preovulatory follicular development and estradiol secretion.
Days to first postpartum ovulation for cows that ovulated were similar in the present study, averaging 24.2 and 28.7 for cows fed 0.35 and $0.47 \% \mathrm{P}$, respectively (Table 4). Resumption of cyclic ovarian function is necessary for normal fertility and calving intervals. The relationship between postpartum anovulatory interval and reproductive performance, however, remains equivocal. Lucy et al. (1992) reported that early postpartum resumption of ovarian cyclicity improved reproductive performance. In contrast, Smith and Wallace (1998) showed that delayed postpartum ovulation was accompanied by increased conception rates and reduced calving-to-conception intervals and services per conception. Delayed postpartum ovulation has also been associated with reduced risk for prolonged luteal cycles (Opsomer et al., 2000). Overall, the results of this study showed that resumption of normal follicular development was not influenced by dietary $P$.

Negative energy balance after parturition has been shown to be positively correlated with the interval to postpartum ovulation (Lucy et al., 1992; Beam and Butler, 1998). Body condition score is a management tool often used to monitor the energy status of a cow in early lactation. Although BCS at calving or first AI has been shown to have no correlation with conception or number of services per conception (Nebel and McGilliard, 1993), the extent of BCS loss between calving and first AI may have an effect on reproductive performance. Reduced conception rates have been reported when cows lost $>1.0$ BCS from calving to first AI (Nebel and McGilliard, 1993). In the present study, BCS change from calving to the end of the voluntary waiting period did not differ between the 0.35 and $0.47 \% \mathrm{P}$ groups (Table 4), which is consistent with the observation on ovarian activity.

The literature on the effect of dietary $\mathrm{P}$ on estrus and ovulation in cattle has been inconsistent. Severe P deficiency has been associated with altered estrus and decreased ovarian activity (Hignett and Hignett, 1952). However, Eckles et al. (1935) reported no effect of dietary $\mathrm{P}$ on ovulation or estrus characteristics, which is consistent with the results of the present study. Similarly, Lopez et al. (2004a,c) reported no difference in estrus duration or intensity in cows fed diets containing 0.38 or $0.48 \%$ and 0.37 or $0.57 \% \mathrm{P}$.

The proportion of ovulatory, anovulatory, and cystic cows did not differ between groups (Table 4). The percentage of cows that developed ovarian follicular cysts ( 11.5 and $14.8 \%$ for the 0.35 and $0.47 \%$ P groups, respectively) was within the range of 6 to $19 \%$ normally observed in dairy cattle (Garverick, 1997). The proportion of anovulatory cows (19.2 and $25.9 \%$, for groups fed 0.35 and $0.47 \% \mathrm{P}$, respectively; $P>0.05$ ) observed was also within the normal range (17 to $29 \%$ ) for cows at 50 to 77 DIM based on serum progesterone concentrations 
Table 4. Ovarian activity, serum progesterone, and BCS of cows fed diets containing 0.35 or $0.47 \% \mathrm{P}$.

\begin{tabular}{|c|c|c|c|c|}
\hline \multirow[b]{2}{*}{ Item } & \multicolumn{2}{|c|}{ Diet } & \multirow[b]{2}{*}{ SEM } & \multirow[b]{2}{*}{$P$} \\
\hline & $0.35 \% \mathrm{P}$ & $0.47 \% \mathrm{P}$ & & \\
\hline Days to first postpartum ovulation ${ }^{1}$ & 24.2 & 28.7 & 2.4 & 0.20 \\
\hline Days to first progesterone increase $\mathrm{e}^{1,2}$ & 35.0 & 40.5 & 4.4 & 0.38 \\
\hline Multiple ovulation rate, ${ }^{3} \%$ & 38.1 & 30.0 & - & 0.58 \\
\hline Proportion of cows with follicular cysts, ${ }^{3} \%$ & 11.5 & 14.8 & - & 0.72 \\
\hline Proportion of anovulatory cows, ${ }^{3} \%$ & 19.2 & 25.9 & - & 0.56 \\
\hline Number of ovulations ( 1 to 60 DIM) & 1.4 & 1.3 & 0.2 & 0.68 \\
\hline Duration estrous cycle, ${ }^{4} \mathrm{~d}$ & 21.0 & 18.8 & 1.0 & 0.12 \\
\hline Peak serum progesterone, ${ }^{4} \mathrm{ng} / \mathrm{mL}$ & 11.2 & 9.8 & 1.0 & 0.35 \\
\hline \multicolumn{5}{|l|}{ Luteal phase progesterone, $\mathrm{ng} / \mathrm{mL}$} \\
\hline First estrous cycle postpartum & 8.1 & 5.6 & 1.1 & 0.12 \\
\hline Second estrous cycle postpartum & 8.7 & 7.2 & 1.9 & 0.58 \\
\hline Ovsynch estrous cycle $^{5}$ & 8.3 & 7.7 & 0.9 & 0.68 \\
\hline \multicolumn{5}{|l|}{$\mathrm{BCS}^{6}$} \\
\hline At calving & 3.37 & 3.37 & 0.07 & 0.99 \\
\hline At 56 DIM & 2.79 & 2.89 & 0.07 & 0.36 \\
\hline Change & 0.58 & 0.48 & 0.06 & 0.24 \\
\hline \multicolumn{5}{|l|}{${ }^{1}$ Ovular cows only. } \\
\hline \multicolumn{5}{|l|}{${ }^{2}$ First increase in progesterone $>1 \mathrm{ng} / \mathrm{mL}$. } \\
\hline \multicolumn{5}{|l|}{${ }^{3}$ During the voluntary waiting period. } \\
\hline \multicolumn{5}{|c|}{${ }^{4}$ All estrous cycles during the voluntary waiting period. } \\
\hline \multicolumn{5}{|c|}{${ }^{5}$ Estrous cycle following last GnRH of Ovsynch. } \\
\hline${ }^{6}$ Using a scale of $1=$ thin to $5=$ fat. & & & & \\
\hline
\end{tabular}

(Moreira et al., 2001) and the absence of corpus luteum (Lopez et al., 2004a).

The inconsistency in the effect of dietary $\mathrm{P}$ on postpartum ovulation may be related to the method used to establish ovulation status. Most of studies combined rectal palpation and timing of the first postpartum rise in concentration of progesterone in serum or milk to determine ovulation. Based on the day serum progesterone rose $>1 \mathrm{ng} / \mathrm{mL}$ for cows that ovulated before the end of the voluntary waiting period, the first ovulation occurred 35.0 and $40.5 \mathrm{~d}$ postpartum for cows fed 0.35 and $0.47 \% \mathrm{P}$, respectively, in the present study (Table 4). Using the same method, Lopez et al. (2004a) reported comparable values for cows fed 0.37 or $0.57 \% \mathrm{P}$. Days to first postpartum ovulation were greater when based on serum progesterone than when ultrasonography was used in the present study (24.2 and $28.7 \mathrm{~d}$ ), indicating a delayed rise in serum progesterone concentration. The treatments, however, did not differ in this measurement with either method. Carstairs et al. (1980) reported $27 \mathrm{~d}$ to first ovulation in primiparous Holstein cows fed $\mathrm{P}$ at or above the requirement suggested by NRC (1989). However, cows fed the low $\mathrm{P}$ diet tended to take longer ( 50 vs. $41 \mathrm{~d}$ ) to attain a serum progesterone concentration of $3 \mathrm{ng} / \mathrm{mL}$. In contrast, De Boer et al. (1981) reported a shorter interval from calving to first ovulation for cows fed $0.34 \%$ than for those fed 0.51 or $0.69 \%$ P. Brodison et al. (1989) reported similar numbers of days to the first rise in milk progesterone concentration for cows fed different amounts of
P. In the present study, the anovulatory status was determined based on ultrasound examinations and progesterone profiles prior to the 60-d voluntary waiting period, and the proportions of anovulatory cows (Table 4 ) were lower than that reported by Lopez et al. (2004a). Lopez et al. (2004a) also reported no difference in days to first postpartum rise in serum progesterone $(>1 \mathrm{ng} /$ $\mathrm{mL}$ ) or anovulatory rate when cows were fed diets containing 0.37 or $0.57 \% \mathrm{P}$. The anovular condition, however, was evaluated based on the absence of a corpus luteum during the first 3 wk after 50 DIM. Consequently, cows that were diagnosed anovular might have ovulated prior to this time.

The incidence of multiple ovulations during the voluntary waiting period was similar, averaging 38.1 and $30.0 \%$ for the low and high $\mathrm{P}$ groups, respectively (Table 4). This result is consistent with the observation of Lopez et al. (2004a) that dietary P had no effect on multiple ovulation rate. The multiple ovulation rates obtained in the present study were, however, greater than those (9.5 to 21.6\%) reported by Lopez et al. (2004a).

\section{Progesterone and Estrous Cycles}

Serum progesterone profiles from calving to the end of the voluntary waiting period showed that the initiation of luteal function did not differ between treatment groups (Table 4). In both groups, cows that were not anestrous ovulated once or twice before the initiation 


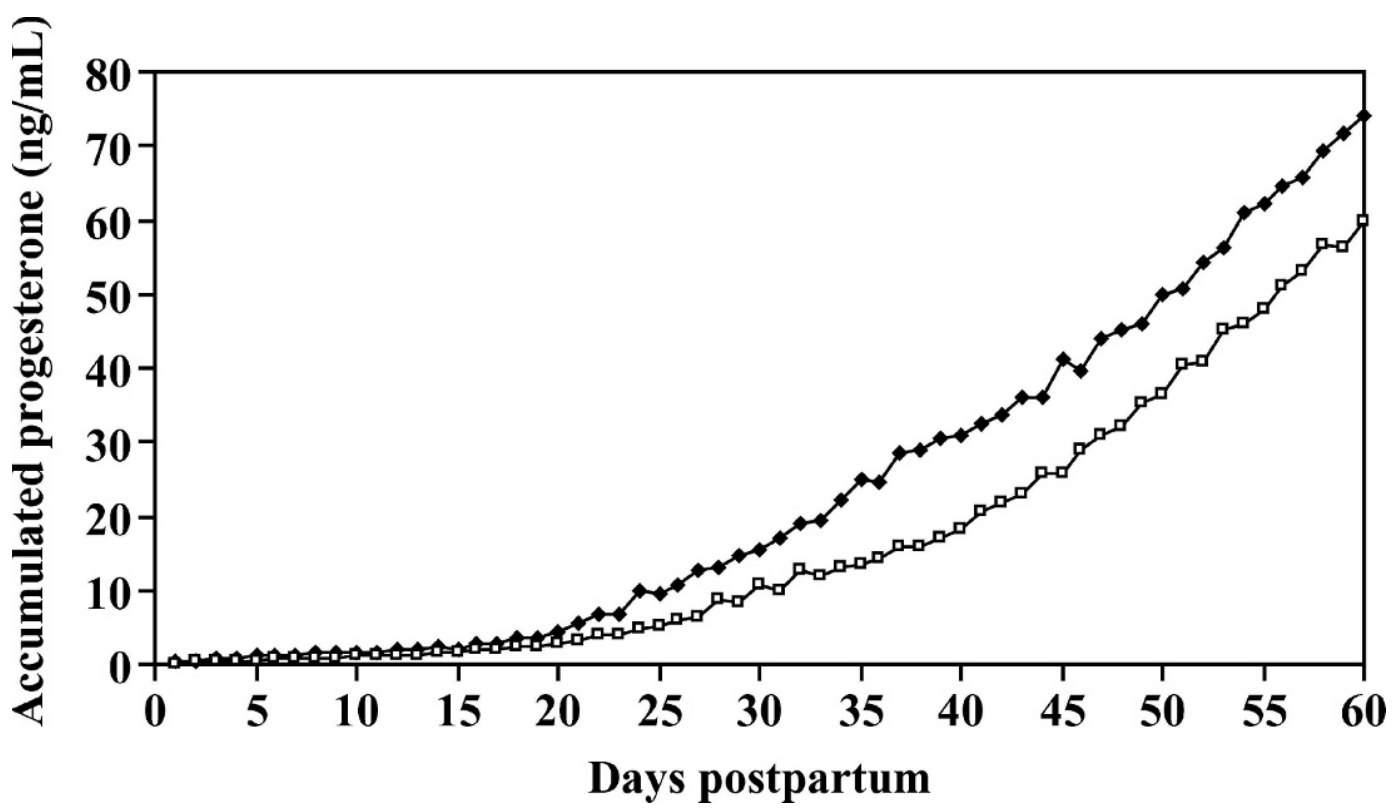

Figure 1. Accumulated serum progesterone concentrations for cows fed diets containing $0.35(\diamond)$ or $0.47 \%(\square) \mathrm{P}(P>0.05)$.

of the Ovsynch protocol. The number of ovulations per treatment did not differ. The estrous cycle tended $(P=$ 0.12 ) to be shorter for cows fed $0.47 \%$ P. Peak serum progesterone concentration during all estrous cycles prior to the end of the voluntary waiting period was 11.2 and $9.8 \mathrm{ng} / \mathrm{mL}$ for the 0.35 and $0.47 \% \mathrm{P}$ groups, respectively. Midluteal phase (d 10 to 15 ) progesterone concentration did not differ between treatments during the second cycle postpartum or during the cycle after the last GnRH injection of the Ovsynch protocol. There was, however, a tendency $(P=0.12)$ for lower luteal phase progesterone concentration for the $0.47 \% \mathrm{P}$ group during the first cycle postpartum. Analysis of accumulated progesterone concentrations during the voluntary waiting period showed that resumption of luteal activity was not influenced by dietary P (Figure 1). The apparently lower progesterone concentration for the $0.47 \% \mathrm{P}$ group might have been due to the tendency for the shorter estrous cycle (18.8 vs. $21.0 \mathrm{~d})$ and the lower midluteal phase progesterone concentration during the first estrous cycle postpartum (Table 4).

\section{Conception and Pregnancy Rates}

Cows were bred using the Ovsynch protocol following the 60-d voluntary waiting period, and the number of days to first service was similar (73.8 and 71.4; Table 5) between dietary $P$ treatments $(0.35$ and $0.47 \%$, respectively). The synchronization rate to Ovsynch based on ovulation after the last GnRH treatment and the subsequent increase in serum progesterone was 61.5 and $69.2 \%$ for the 0.35 and $0.47 \% \mathrm{P}$ groups, respectively, both lower than that (87\%) reported by Vasconcelos et al. (1999). The conception rate of first service (32.0 and $44.4 \%$ ), pregnancy loss measured between 30 and $60 \mathrm{~d}$ after $\mathrm{AI}$ (25.0 and $33.3 \%$ ), overall pregnancy rate at 200 DIM (60.9 and 60.0\%), and the number of services per conception (2.1 and 1.9) did not differ with dietary P amount (0.35 and $0.47 \%$, respectively). Hignett and Hignett (1952) reported increased conception rates with $\mathrm{P}$ supplementation under extremely low $\mathrm{P}$ feeding conditions. Our study compared adequate and excessive amounts of P based on the current NRC (2001) recommendations. Steevens et al. (1971) reported a decreased number of services per conception during the 2nd yr of feeding 0.53 to 0.56 compared with $0.40 \% \mathrm{P}$. Other studies (Eckles et al., 1935; Noller et al., 1977; Brodison et al., 1989) reported no relationship between dietary $P$ and reproductive performance. A summary of 8 studies (Wu et al., 2000) showed no difference in reproductive performance between cows fed low $(0.32$ to $0.40 \%)$ and high (0.39 to $0.55 \%)$ amounts of P. Results of the present study are in agreement with those of Lopez et al. (2004a) using cows fed diets containing 0.37 or $0.57 \%$ P.

First service conception rates were similar to those reported previously using Ovsynch in lactating cows (Pursley et al., 1995). Pregnancy losses between 30 and $60 \mathrm{~d}$ post-AI (25.0 and 33.3\%; Table 5) were greater than those reported previously (Moreira et al., 2001; Lopez et al., 2004a). Also, number of services per conception for pregnant cows was lower than that reported by Lopez et al. (2004a), and pregnancy rates at 200 
Table 5. Reproductive performance of cows fed diets containing 0.35 or $0.47 \% \mathrm{P}$.

\begin{tabular}{lcccc}
\hline & \multicolumn{3}{c}{ Diet } & \\
\cline { 2 - 3 } Item & $0.35 \% \mathrm{P}$ & $0.47 \% \mathrm{P}$ & SEM & $P$ \\
\hline Days to first service $^{1}$ & 73.8 & 71.4 & 1.8 & 0.34 \\
Days open $^{1}$ & 105.7 & 102.0 & 9.2 & 0.78 \\
Ovulation synchronization rate, $^{2} \%$ & 61.5 & 69.2 & - & 0.56 \\
First service conception rate, \% $_{\text {Pregnancy loss (30 to 60 d after AI), }}{ }^{2} \%$ & 32.0 & 44.4 & - & 0.36 \\
Overall pregnancy rate, $^{3} \%$ & 25.0 & 33.3 & - & 0.69 \\
Number of services per conception & 60.9 & 60.0 & - & 0.95 \\
\hline
\end{tabular}

${ }^{1}$ For cows pregnant by 200 DIM.

${ }^{2}$ First service only.

${ }^{3}$ Pregnancy rate at 200 DIM.

DIM were lower than those reported elsewhere using the Ovsynch protocol (Vasconcelos et al., 1999; Moreira et al., 2001; Lopez et al., 2004a). The difference in the overall pregnancy rate may be attributable to the greater pregnancy losses from 30 to $60 \mathrm{~d}$ after $\mathrm{AI}$ in the current study. There was a tendency $(P=0.07)$ for the overall pregnancy rate to be greater for cows that ovulated their first dominant follicle than for those whose follicles either regressed or formed cysts $(72 \%$ vs. $45 \%$ ). Days open for cows that were pregnant by 200 DIM were not different between the $\mathrm{P}$ treatments.

\section{Serum $\mathrm{Ca}$ and $\mathrm{P}$ Concentration}

Serum concentrations of inorganic $\mathrm{P}$ and $\mathrm{Ca}$ were lower for the $0.35 \% \mathrm{P}$ group than for the $0.47 \% \mathrm{P}$ group during wk 1 to 3 after calving, and $\mathrm{Ca}: \mathrm{P}$ was approximately 1.4:1 (Table 6). Although the mean serum $P$ concentration during the first $12 \mathrm{wk}$ of lactation was lower for the low $\mathrm{P}$ group than for the high $\mathrm{P}$ group (6.1 vs. $7.0 \mathrm{mg} / \mathrm{dL})$, no difference in Ca concentration was observed. Overall, serum $\mathrm{P}$ concentration was greater for the $0.47 \% \mathrm{P}$ group than for the $0.35 \% \mathrm{P}$ group

Table 6. Serum $\mathrm{P}$ and $\mathrm{Ca}$ concentrations in cows fed diets containing 0.35 or $0.47 \% \mathrm{P}$.

\begin{tabular}{lllll}
\hline & \multicolumn{3}{c}{ Diet } & \\
\cline { 2 - 3 } Item & $0.35 \% \mathrm{P}$ & $0.47 \% \mathrm{P}$ & SEM & $P$ \\
\cline { 2 - 3 } & & & & \\
P & 5.5 & 6.1 & 0.2 & 0.01 \\
wk 1 & 5.6 & 6.6 & 0.3 & 0.01 \\
wk 2 and 3 & 6.1 & 7.0 & 0.2 & 0.01 \\
First 3 mo postpartum & & & & \\
Ca & 7.4 & 8.3 & 0.2 & 0.01 \\
wk 1 & 8.2 & 8.7 & 0.2 & 0.03 \\
wk 2 and 3 & 8.7 & 9.0 & 0.1 & 0.11 \\
First 3 mo postpartum & & & & \\
\hline
\end{tabular}

(Figure 2). Increased serum inorganic $\mathrm{P}$ concentrations caused by increased dietary $\mathrm{P}$ intake have been reported (Steevens et al., 1971; Hurley et al., 1982; Wu et al., 2000; Lopez et al., 2004b), but the increase has not been accompanied by improved reproductive performance. Using P-deficient diets, Eckles et al. (1935) reported that reproductive performance was not affected, although blood $\mathrm{P}$ was as low as one-half of the normal levels. The values observed for the low $\mathrm{P}$ diet in the present study were within ranges typically observed in lactating dairy cows (NRC, 2001). Serum Ca concentration after parturition may reflect bone resorption, and the fact that the concentration was lower for the $0.35 \%$ $\mathrm{P}$ diet would suggest that this amount of $\mathrm{P}$ was not low enough to stimulate further bone resorption compared with the $0.47 \% \mathrm{P}$ diet.

\section{Lactation Performance and P Excretion}

Group average DMI was 20.7 and $21.0 \mathrm{~kg} / \mathrm{d}$ for cows on the 0.35 and $0.47 \% \mathrm{P}$ treatments, respectively. Previous studies showed that DMI was not affected when

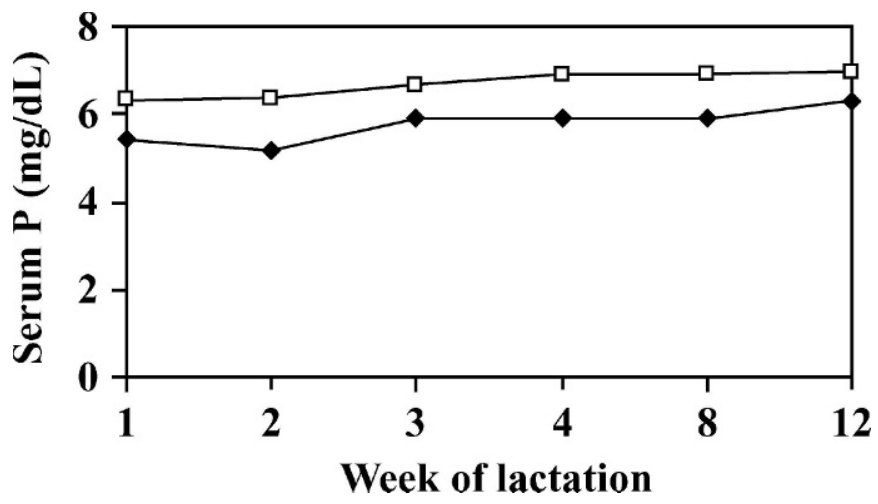

Figure 2. Serum inorganic $P$ concentrations for cows fed diets containing $0.35(-)$ or $0.47 \%(\square) \mathrm{P}$. The mean for the $0.47 \%$ group was greater $(P<0.05)$ than that for the $0.35 \% \mathrm{P}$ group. 
Table 7. Milk production of cows fed diets containing 0.35 or $0.47 \%$ P.

\begin{tabular}{lcccc}
\hline & \multicolumn{2}{c}{ Diet } & & \\
\cline { 2 - 3 } Item & $0.35 \% \mathrm{P}$ & $0.47 \% \mathrm{P}$ & SEM & $P$ \\
\hline Milk yield, ${ }^{1} \mathrm{~kg} / \mathrm{d}$ & 40.5 & 39.0 & 1.3 & 0.41 \\
Milk fat, \% & 3.32 & 3.32 & 0.08 & 0.98 \\
Milk protein, \% & 2.93 & 2.92 & 0.03 & 0.73 \\
Lactose, \% & 4.92 & 4.96 & 0.05 & 0.55 \\
Milk SCC, 1000/mL & 326 & 268 & 80 & 0.61 \\
MUN, mg/dL & 13.1 & 12.0 & 0.4 & 0.06 \\
\hline
\end{tabular}

${ }^{1}$ Based on the first $40 \mathrm{wk}$ of lactation.

dietary $\mathrm{P}$ was varied from 0.31 to $0.67 \%$ (Wu et al., 2000 ) but decreased with $0.24 \% \mathrm{P}$ over extended feeding periods (Valk and Šebek, 1999). Dietary P amount did not affect mean milk yield for the first $40 \mathrm{wk}$ of lactation (Table 7). The milk yield values appeared high, and the DHIA records might be inflated. None of the milk components was affected by dietary $\mathrm{P}$ except for milk urea $\mathrm{N}$, which tended to be lower $(P=0.06)$ for the $0.47 \%$ $\mathrm{P}$ group, although both concentrations were within the acceptable range of 10 to $16 \mathrm{mg} / \mathrm{dL}$ (Jonker et al., 1998). Milk urea $\mathrm{N}$ concentrations $>15 \mathrm{mg} / \mathrm{dL}$ have been associated with reduced fertility (Rajala-Schultz et al., 2001). Accordingly, the concentrations observed in this study would not have had an effect on the reproductive measurements. Similar milk production is consistent with previous reports that showed no increase in milk production when cows were fed diets containing $>0.37 \%$ P (Lopez et al., 2004b). Wu et al. (2000) suggested that diets should contain $>0.30 \% \mathrm{P}$ for cows producing 7500 to $9000 \mathrm{~kg}$ per lactation, as milk yield dropped during the last one-third of the lactation for cows fed $0.31 \% \mathrm{P}$ in their experiment.

Fecal P concentrations were lower for cows fed $0.35 \%$ than for those fed $0.47 \% \mathrm{P}$ at all collection times during the first 16 wk of lactation (Figure 3). Mean concentra-

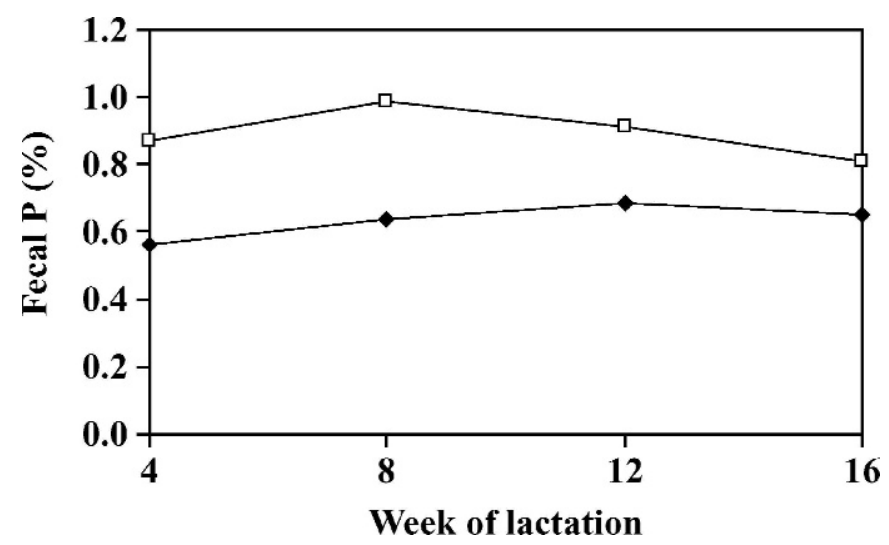

Figure 3. Fecal $\mathrm{P}$ concentrations for cows fed diets containing

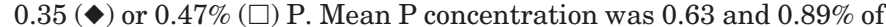
$\mathrm{DM}$ (SEM $0.05 ; P<0.01$ ) for the 0.35 and $0.47 \% \mathrm{P}$ groups, respectively. tion obtained was 0.63 and $0.89 \%$ for the 0.35 and $0.47 \%$ $\mathrm{P}$ groups, respectively, and $29 \%$ lower for cows fed the lower P diet. Similarly, Wu et al. (2000) reported 0.51, 0.73 , and $0.90 \%$ fecal $\mathrm{P}$ for cows fed diets containing $0.31,0.40$, or $0.49 \% \mathrm{P}$, respectively. This reduction in fecal $\mathrm{P}$ concentration would reduce $\mathrm{P}$ excretion from 20 to $14 \mathrm{~kg}$ per lactation, assuming no changes in DMI (using $21 \mathrm{~kg} / \mathrm{d}$ ) or digestibility (using 65\%), and would reduce the land requirement for recycling fecal $\mathrm{P}$ from 0.7 to 0.5 ha per cow, assuming a $\mathrm{P}$ application rate of $30 \mathrm{~kg} / \mathrm{ha}$.

\section{CONCLUSIONS}

Varying dietary $\mathrm{P}$ from 0.35 to $0.47 \%$ had no effect on postpartum resumption of normal ovarian activity, progesterone concentration, or reproductive performance, although blood P concentration was elevated. The increase in dietary $\mathrm{P}$ did not affect milk yield or composition, but resulted in increased fecal $\mathrm{P}$ concentration. These results suggest that feeding $\mathrm{P}$ according to the 2001 NRC guidelines should not negatively impact postpartum ovarian activity, reproductive performance, or milk production.

\section{ACKNOWLEDGMENTS}

This project was supported in part from the USDA Pennsylvania State University Improved Dairy Management Practices Program, award number 200134281-11219. The study would not have been possible without the cooperation of Dan Ulmer, who provided the animals and facility for conducting the experiment. Contributions to the development of research hypothesis and design from L. C. Griel, M. L. O'Connor, and R. S. Kensinger are appreciated. The authors also appreciate the technical assistance received from $\mathrm{E}$. Smoyer, A. Brown, G. A. Varga, and C. R. Baumrucker.

\section{REFERENCES}

Association of Official Analytical Chemists, Int. 1990. Official Methods of Analysis. Vol. I. 15th ed. AOAC, Arlington, VA.

Beam, S. W., and W. R. Butler. 1998. Energy balance, metabolic hormones, and early postpartum follicular development in dairy cows fed prilled lipid. J. Dairy Sci. 81:121-131.

Brodison, J. A., E. A. Goodall, J. D. Armstrong, D. I. Givens, F. J. Gordon, W. J. McCaughey, and J. R. Todd. 1989. Influence of dietary phosphorus on the performance of lactating dairy cattle. J. Agric. Sci. (Camb.) 112:303-311.

Carnahan, D. L. 1974. Mineral relationship to reproduction in dry lot dairy operations. Pages 1-5 in Proc. Annu. Mtg. Am. Vet. Soc. for Study of Breeding Soundness, Columbia, MO. Soc. Theriogenology, Hastings, NE.

Carstairs, J. A., D. A. Morrow, and R. S. Emery. 1980. Postpartum reproductive function of dairy cows as influenced by energy and phosphorus status. J. Anim. Sci. 51:1122-1130.

De Boer, G., J. G. Buchanan-Smith, J. K. Macleod, and J. S. Walton. 1981. Responses of dairy cows fed alfalfa silage supplemented 
with phosphorus, copper, zinc, and manganese. J. Dairy Sci. 64:2370-2377.

Dou, Z., J. D. Ferguson, J. Fiorini, J. D. Toth, S. M. Alexander, L. E. Chase, C. M. Ryan, K. F. Knowlton, R. A. Kohn, A. B. Paterson, J. T. Sims, and Z. Wu. 2003. Phosphorus feeding levels and critical control points on dairy farms. J. Dairy Sci. 86:3787-3795.

Eckles, C. H., L. S. Palmer, T. W. Gullickson, C. P. Fitch, W. L. Boyd, L. Bishop, and J. W. Nelson. 1935. Effects of uncomplicated phosphorus deficiency on estrous cycle, reproduction, and composition of tissues of mature dairy cows. Cornell Vet. 25:22-43.

Edmonson, A. J., I. J. Lean, L. D. Weaver, T. Farver, and G. Webster. 1989. A body condition scoring chart for Holstein dairy cows. J. Dairy Sci. 72:68-78.

Fortune, J. E., J. Sirois, A. M. Turzillo, and M. Lavoir. 1991. Follicle selection in domestic ruminants. J. Reprod. Fertil. Suppl. 43:187-198.

Garverick, H. A. 1997. Ovarian follicular cysts in dairy cows. J. Dairy Sci. 80:995-1004.

Hignett, S. L., and P. G. Hignett. 1952. The influence of nutrition on reproductive efficiency in cattle. II. The effect of the phosphorus intake on ovarian activity and fertility of heifers. Vet. Rec. 64:203-206.

Hurley, W. L., L. A. Edgerton, D. Olds, and R. W. Hemken. 1982. Estrous behavior and endocrine status of dairy heifers with varied intakes of phosphorus. J. Dairy Sci. 65:1979-1986.

Jonker, J. S., R. A. Kohn, and R. A. Erdman. 1998. Using milk urea nitrogen to predict nitrogen excretion and utilization efficiency in lactating dairy cows. J. Dairy Sci. 81:2681-2692.

Lopez, H., F. D. Kanitz, V. R. Moreira, L. D. Satter, and M. C. Wiltbank. 2004a. Reproductive performance of dairy cows fed two concentrations of phosphorus. J. Dairy Sci. 87:146-157.

Lopez, H., F. D. Kanitz, V. R. Moreira, M. C. Wiltbank, and L. D. Satter 2004b. Effect of dietary phosphorus on performance of lactating dairy cows: Milk production and cow health. J. Dairy Sci. 87:139-145.

Lopez, H., Z. Wu, L. D. Satter, and M. C. Wiltbank. 2004c. Effect of dietary phosphorus concentration on estrous behavior of lactating dairy cows. Theriogenology 61:437-445.

Lucy, M. C., C. R. Staples, W. W. Thatcher, P. S. Erickson, R. M. Cleale, J. L. Firkins, M. R. Murphy, J. H. Clark, and B. O. Brodie. 1992. Influence of diet composition, dry matter intake, milk production, and energy balance on time of postpartum ovulation and fertility in dairy cows. Anim. Prod. 54:323-331.

Moreira, F., C. Orlandi, C. A. Risco, R. Mattos, F. Lopes, and W. W. Thatcher. 2001. Effects of pre-synchronization and bovine somatotropin on pregnancy rates to a timed artificial insemination protocol in lactating dairy cows. J. Dairy Sci. 84:1646-1659.

National Research Council. 1989. Nutrient Requirements of Dairy Cattle. 6th rev. ed. Natl. Acad. Sci., Washington, DC.

National Research Council. 2001. Nutrient Requirements of Dairy Cattle. 7th rev. ed. Natl. Acad. Sci., Washington, DC.

Nebel, R. L., and M. L. McGilliard. 1993. Interactions of high milk yield and reproductive performance in dairy cows. J. Dairy Sci. 76:3257-3268.

Noller, C. H., A. G. Castro, W. E. Wheeler, D. L. Hill, and N. J. Moeller. 1977. Effect of phosphorus supplementation on growth rate, blood minerals, and conception rate of dairy heifers. J. Dairy Sci. 60:1932-1940.

Opsomer, G., Y. T. Gröhn, J. Hertl, M. Coryn, H. Deluyker, and A. de Kruif. 2000. Risk factors for postpartum ovarian dysfunction in high producing dairy cows in Belgium: A field study. Theriogenology 53:841-857.

Pursley, J. R., M. O. Mee, and M. C. Wiltbank. 1995. Synchronization of ovulation in dairy cows using $\mathrm{PGF}_{2 \alpha}$ and $\mathrm{GnRH}$. Theriogenology 44:915-923.

Rajala-Schultz, P. J., W. J. A. Seville, G. S. Frazer, and T. E. Wittum. 2001. Association between milk urea nitrogen and fertility in Ohio dairy cows. J. Dairy Sci. 84:482-489.

Robertson, J. B., and P. J. Van Soest. 1981. The detergent system of analysis and its application to human food. Page 123 in The Analysis of Dietary Fiber in Foods. W. P. T. Kames and O. Theander, ed. Marcel Dekker, Inc., New York, NY.

SAS User's Guide: Statistics. 1999. Version 8.0. SAS Inst., Inc., Cary, NC.

Scharp, D. W. 1979. Effects of adding superphosphate to the drinking water on the fertility of dairy cows. Aust. Vet. J. 55:240-243.

Schmitt, E. J., T. Diaz, C. M. Barros, R. L. de la Sota, M. Drost, E. W. Fredriksson, C. R. Staples, R. Thorner, and W. W. Thatcher. 1996. Differential response of the luteal phase and fertility in cattle following ovulation of the first-wave follicle with human chorionic gonadotropin or an agonist of gonadotropin-releasing hormone. J. Anim. Sci. 74:1074-1083.

Sirois, J., and J. E. Fortune. 1988. Ovarian follicular dynamics during the estrous cycle in heifers monitored by ultrasonography. Biol. Reprod. 39:308-317.

Smith, M. C. A., and J. M. Wallace. 1998. Influence of early postpartum ovulation on the re-establishment of pregnancy in multiparous and primiparous dairy cattle. Reprod. Fertil. Dev. 10:207216.

Steevens, B. J., L. L. Bush, J. D. Stout, and E. I. Williams. 1971. Effects of varying amounts of calcium and phosphorus in rations for dairy cows. J. Dairy Sci. 54:655-661.

Tallam, S. K., T. F. Duffield, K. E. Leslie, R. Bagg, P. Dick, G. Vessie, and J. S. Walton. 2003. Ovarian follicular activity in lactating Holstein cows supplemented with monensin. J. Dairy Sci. 86:3498-3507.

Theiler, A., H. H. Green, and P. J. DuToit. 1928. Studies in mineral metabolism. III. Breeding of cattle on phosphorus deficient pasture. J. Agric. Sci. (Camb.) 18:369-371.

Valk, H., and L. B. J. Šebek. 1999. Influence of prolonged feeding of limited amounts of phosphorus on dry matter intake, milk production and body weight of dairy cows. J. Dairy Sci. 82:2157-2163.

Vasconcelos, J. L. M., R. W. Silcox, G. J. M. Rosa, J. R. Pursley, and M. C. Wiltbank. 1999. Synchronization rate, size of ovulatory follicle, and pregnancy rate after synchronization of ovulation beginning on different days of the estrous cycle in lactating dairy cows. Theriogenology 52:1067-1078.

Wu, Z., and L. D. Satter. 2000. Milk production and reproductive performance of dairy cows fed two concentrations of phosphorus for two years. J. Dairy Sci. 83:1052-1063.

Wu, Z., L. D. Satter, and R. Soja. 2000. Milk production, reproductive performance, and fecal excretion of phosphorus by dairy cows fed three amounts of phosphorus. J. Dairy Sci. 83:1028-1041. 